\title{
Proactivity versus self-efficacy in the process of developing a career by the youth
}

\section{KEYWORDS}

proactivity, professional career, self-efficacy in action, labour market, youth

\begin{abstract}
Myszka-Strychalska Lucyna, Proactivity versus self-efficacy in the process of developing a career by the youth. Culture - Society - Education no. 1(17) 2020, Poznań 2020, pp. 163-178, Adam Mickiewicz University Press. ISSN 23000422. DOI 10.14746/kse.2020.17.8.2
\end{abstract}

The contemporary labour market is characterised by broadly understood flexibility which conditions the uncertainty of the professional situation of a person participating therein. One of the factors increasing their chances to have a successful career are not only relevant competences, qualifications and proactive behaviours to the benefit of their own development, but also their trust in their own abilities. In this article it has been attempted to confirm the thesis on the existence of co-dependence between the individual's proactivity and self-efficacy in the process of developing a professional career. To this end, a review of selected theoretical depictions on both, constructs and results of research explorations specifying mutual relations, was conducted. The observations made have both, theoretical and practical implications that are interesting in cognitive terms. The analysis thereof may prove to be especially important with regard to young people who are preparing to enter the labour market.

\section{Introduction}

In line with contemporary career conceptions, a human is attributed with more and more responsibility for the course of professional development. He or she is,

\footnotetext{
* ORCID https://orcid.org/0000-0003-2973-1379.
} 
in fact, considered to be an individual who is planning and managing their own career path. In this context, it seems justified to subject the construct of individual proactivity to in-depth analysis (Griffin, Neal, Parker, 2007). An individual who undertakes an activity aimed at changing the reality in compliance with the perspective set by future objectives, aspirations and professional needs, assumes the responsibility for influencing this process of change by using to this end accumulated resources. Proactive persons are also described as taking "personal initiative" (Fay, Frese, 2001), "agent of changes" (Bateman, Crant, 1993), "creative individualist", "innovator of a role" (Schein, 1971), or "individuals acting independently" (Bańka, 2009). These expressions indicate the person's significant impact on the course of their career, which underlines their subjective agency and independence in this area.

The analysis of the proactivity construct with regard to the professional career allows extending the perspective of analysing this area of human activity with inclusion of various important factors before they are fully defined or materialised. In the theory of proactive coping, a human is perceived as an entity able to make decisions and take actions in the face of predictable situations. Therefore, a key criterion to identify proactive behaviours is whether the individual predicts, plans and attempts to create a future result, which has an impact on them or on the environment (Grant, Ashford, 2008; Parker et al., 2006).

As a consequence of the conglomerate of contemporary transformations of the labour market, proactivity of an individual is often much more important for the course of their career path than support provided to the youth by educational institutions or employers who employ new employees. This characteristic does, in fact, contribute to taking independent initiatives that can generate beneficial results in the future. Adaptable persons are characterised with the ability to flexibly function in the reality of permanent transformations, which proves to be beneficial for their career capital. Career self-efficacy responsible for the person's belief in effective participation in the labour market is an inseparable factor conditioning successful course of professional development in the unstable world. Observing this category proves to be of a significant importance in the context of the individual's coping with challenges of everyday life, including those related to professional satisfaction, successful career, as well as self-perception and shaping identity.

Therefore, understanding dependency between the individual's proactivity and self-efficacy becomes one of the crucial tasks of social sciences, the area of interest of which encompasses issues related to the professional career and preparing youth to active participation in the labour market. Recognition of these constructs 
will allow "more effectively predict how people will behave and what will be the result of their actions by learning about their point of view on how they assess their abilities" (Bańka, 2004: 204).

\section{Proactivity in career}

In the context of the discussed subject matter, it is worth conducting a more indepth analysis of the theory of proactive coping by German researchers Ralph Schwarzer and Steffen Taubert (1999). This depiction enriches the scientific knowledge in the scope of the analysis of cognitive processes and human behaviours in difficult and stressful situations. Since it focuses on recognising factors reinforcing achieving objectives by the individual, their engagement and self-development, it may prove to be helpful in recognising various life situations, including those related to the professional activity (see Ślebarska, 2017).

- In accordance with the assumptions of the aforementioned theory, proactive coping "includes autonomous and independent setting of challenging objectives and consequent implementation thereof (...) concerns self-regulatory processes of achieving objectives and strives to explain what motivates people to pursue ambitious objectives and engage in self-development" (Schwarzer, Taubert, 1999: 86). Creators of this theory explicitly underline that proactive coping should be distinguished from other types of behaviours, such as: reactive coping, anticipatory coping, or preventive coping (Schwarzer, Taubert, 2002). Reactive approaches are applied by an individual in the situation of already existing events and constitute a product of their reaction only in the case of specific circumstances. (See: Albion, Fernie, Burton, 2005). In the reflection referring to the professional career requiring planning and of dynamic and often unpredictable character, this perspective is insufficient. Therefore, the theory of proactive coping provides for taking into consideration in the analysis of future challenges taken up by the individual on their own initiative.

Proactive persons undertake activities of constructive significance for the vision of the future adopted by them (usually in the long-term perspective). They focus on collecting resources that may prove to be helpful in personal development, whereas, they treat any threats in categories of challenges. Proactive people concentrate on managing set objectives, implementation of which will contribute to the improvement of the quality of their lives and increase their productiveness. Cognitive assessment and identification of motivation constitute crucial processes 
preceding any activities undertaken by the individual. Due to the fact that proactive coping is primarily of auto-regulatory character and is aimed at achieving adopted assumptions, self-efficacy, understood as optimistic belief that one can initiate and maintain difficult directions of activity, constitutes an important factor conditioning success thereof. (Schwarzer, Taubert, 2002)

R. Schwarzer and S. Taubert stress that proactive behaviour should be distinguished from proactive attitude, which, in the conception presented by them, is understood as a certain disposition, inherent human tendency. This attitude conditions proactive coping that influences shaping proactive personality specified by such features as resourcefulness, responsibility, values and vision. In accordance with such assumptions, a proactive person is convinced of the existence of internal and external resources that allow achievement of the set objectives. They take an analytical approach to various situations and consider them in categories of their own obligations to future events and execution of tasks. They are decidedly more focused on the latter which contributes to meeting challenges in a manner compliant with their own values (Schwarzer, Taubert, 2002).

It is worth stressing here that compilations on proactivity include analysis presenting it as both, a personality feature (Crant, 2000; Frese et al., 1996) and as an attitude directed at changing personal resources (Hobfoll, 2006). Augustyn Bańka underlines that it is impossible to completely distinguish proactivity as a personality feature from proactivity as an attitude of engagement, which is triggered by specific situations and circumstances (Bańka, 2009: 18). It should be, in fact, noticed that on the one hand, the form of proactivity of an individual is conditioned by his or her predispositions and on the other hand, by the context of his or her life and pressure of the environment. Therefore, in some depictions, proactive behaviours are presented as a series of related acts and phases (Grant, Ashford, 2008), whereas, others are concentrated on the analysis of variations of output variables influencing the individual's professional success.

The aforementioned A. Bańka $(2009 ; 2015 ; 2016)$ situates deliberations on proactivity in interactive perspective. This researcher defines it as "the individual's intentional activation of activity in real time without the specific intention of immediate implementation of the final objective" (Bańka, 2015: 98). In compliance with this understanding, the essence thereof consists in the human's willingness to change the surrounding environment, which is to be helpful in maintaining the sense of identity, trust in oneself or effectiveness of undertaken ventures. Thus, due to the invaluable role of proactivity in difficult situations and accompanying reflective engagement of the individual, A. Bańka considers it as a form of resourcefulness and adaptation to the conditions of an unpredictable world (Bańka, 2015: 98). 
In thus outlined perspective it is justified to analyse the construct of proactivity with regard to the professional career and the contemporary labour market. Apart from openness and flexibility, it is considered to be one of the features specifying maturity to career (Bańka, 2009). Thus, proactivity in this sphere of human participation will be manifested in the high level of initiatory approach in undertaken professional activities, using emerging opportunities to succeed and effective coping with difficulties. Activities undertaken by persons with a high level of proactivity can have a beneficial impact on the changes to the whole organisation. Measures of proactive behaviours in career are considered to be achievement of objectives set by the individual and needs related to their achievements and aspirations (Fay, Frese, 2001; Frese et al., 1997). Efficacy thereof is conditioned by the continuous exploration of the environment which provides information necessary to make decisions and plan another activities, as well as is useful in meeting new people and building a group of contacts with various persons, the so-called: networking. Proactivity increases the individual's subjective sense of succeeding in career. This regularity results from the fact that persons who take care of their own professional development often choose working environments characterised with independence and the possibility of self-determination, since it facilitates constructing their career in the desired direction (Seibert et al., 1999). Moreover, proactive persons show higher abilities to adapt to new workplaces and effectively adjust them to their needs and abilities (Ślebarska, 2017; Crant, 1995). Therefore, it can be stated that they are consciously and responsibly monitoring the course of their career and managing their development.

\section{Self-efficacy in career construction}

Introduction of the concept of perceived self-efficacy to social sciences is attributed to Albert Bandura (1977), who dealt with the issue of modification of human behaviours. His works proved that belief in one's own abilities contributes to bigger engagement in executed projects and beneficially impacts achieved results. Selfefficacy is identified with the individual's subjective belief that he or she is able to undertake and control specific activities, in other words, it is a conviction of own competences conditioned by various personal and situational factors.

Definition of self-efficacy constructed by A. Bańka, according to which it is "the conducted assessment of trust in their own abilities of organising and enforcing a specific direction of activity requiring execution of various activities at a specific level of proficiency, effectiveness and productivity" (Bańka, 2006: 82), draws 
attention to one more dimension of this construct. In fact, it indicates that the individual, who believes in their own abilities, consciously undertakes actions aimed at the achievement of specific objectives and decides on the level of engagement in implementation thereof. The individual hopes that the undertaken activities will allow them to overcome potentially difficult situations that are to happen in the future (Maddux, Lewis, 1995).

A. Bandura distinguishes four sources of information conditioning the development of the individual's self-efficacy, such as: experiences related to the achievement of goals and successes, observing effectiveness of activities undertaken by other social life participants (modelling, substitute experience), verbal persuasions, that is, incentives obtained from the environment that develop the belief of having competences allowing successful completion of ventures, the ability to manage stress and reduce emotional tensions (Bandura, 2015: 87). The individual who enjoys prosperity for a long period of time does not lose selfefficacy in the situation of temporary failures, since such failures motivate them to continue to make an effort. This regularity results from the fact that the power of motivation and determination in performed activities is conditioned by the person's trust in oneself and not objective situational factors. Observation of other people's successes allows the person to form a belief that he or she will be able to cope in similar circumstances. Thus, they gain experience without direct participation. Another stimulus reinforcing the individual's self-efficacy constitutes external information on the skills he or she has verbalised by his companions, which may turn out helpful in the execution of the task. The significance of their influence is more effective if confirmed with facts. An important role in the assessment of own abilities is also played by the somatic and emotional condition. A positive mood and resilience to stress enhance noticing in oneself reserves of self-efficacy, whereas, a bad mood, pain and exhaustion - decrease it significantly.

Career self-efficacy is a type of specific self-efficacy (Lent, Hackett, 1987; Betz, 1992; Bańka, 2016) related to the individual's trust in oneself with regard to planning, monitoring and managing their own path of professional development. It proves to be an exceptionally important characteristic for youth in the period of double transition from adolescence to adulthood and from education to the labour market, as it constitutes a component of their career capital which is of some significance for shaping a satisfactory professional future (Turska, 2014). It allows the individual to perceive oneself as a person able to undertake activities and achieve objectives, which motives them to continue professional activities and achieve their own aspirations (Krauze, 2012). Additionally, persons identifying themselves 
with self-efficacy indicate higher satisfaction with performed work and have actual professional achievements (Klassen, Chiu, 2010).

Observing the construct of self-efficacy in the youth's careers has its prognostic value. In the case of studying the youth, it impacts their behaviours related to shaping their own career, such as the selection of a university or educational achievements (Lent. Hackett, 1987). Furthermore, the level of the individual's trust in their own competences is manifested at the initial period of professional work, it allows predicting his or her promotions and successes achieved at a later time (Cervone, 1997). Thus, the category of career self-efficacy can be used not only to assess individual beliefs regarding chances to successfully complete the set task, but also as a measure of effectiveness of functioning in work environments. To a certain degree, it estimates the individual's preparation to enter the labour market, maturity to professional career.

It is worth mentioning that the construct supplementing deliberations on mutual relations between self-efficacy and proactivity in the process of constructing professional career consists in locating the control. While the conviction of own efficacy concentrates on the belief in the ability to trigger certain activities, whereas, pro-activity is related to undertaking activities aimed at triggering changes in the environment, location of control constitutes the individual's conviction that specific efforts will produce desired results. In the context of shaping their own professional career, it is important to reinforce the individual's internal control, as it conditions their awareness of influencing the course of events, which results in a higher assessment of chances to achieve success in activities, making decisions independently and having ambitious aspirations (Drwal, 1995). Moreover, the internal location of control accompanying strong self-efficacy reinforces the individual's skills related to coping in a difficult situation (Bańka, 2016: 10).

The discussed discourse implies noticing mutual relations between proactivity and self-efficacy (features characteristic for persons identifying with such properties have been compiled in the table). An intentional creation of reality constitutes the essence of proactive activities. The individual focused on the achievement of a specific objective will consequently pursue implementation thereof. In thus outlined perspective, the reference to belief in their own abilities to control events can be successfully noticed. Self-efficacy influences the individual's thoughts, feelings, motivation and attitude to tasks, which, in consequence conditions made decisions and set objectives. They are considered to be a factor determining the change in behaviours on the grounds of the assessment of the situation and results in searching for an effective way of coping in an unknown situation (Maddux, Lewis, 1995). All of these properties are exceptionally important in subjective construction of a professional 
career. Self-trust constitutes one of the personality features preventing indecision resulting from institutional or structural (education, labour market) conditions that have a favourable impact on the development of proactivity (Bańka, 2013).

Table 1. Characteristics of a proactive person and a person with high self-efficacy

\begin{tabular}{|c|c|}
\hline Proactive person & Person with high self-efficacy \\
\hline $\begin{array}{l}\text { - explores the environment in order to recognise } \\
\text { factors allowing them to achieve adopted } \\
\text { assumptions; } \\
\text { - their abilities to shape the environment exceed } \\
\text { the possibilities of shaping their behaviours by } \\
\text { the environment; } \\
\text { - is change-oriented, focused on the } \\
\text { maximisation of own achievements, they are } \\
\text { forward-looking; } \\
\text { - forces the environment to function in } \\
\text { compliance with their current needs, significant } \\
\text { for events that are to happen in the future; } \\
\text { - evaluates their activities and take initiative; } \\
\text { - develops new ways of achieving set objectives, } \\
\text { notice opportunities; } \\
\text { - is characterised with risk awareness and } \\
\text { responsibility ("responsible engagement"; } \\
\text { Morrison and Phelps; 1999), therefore, they } \\
\text { make various attempts at actions (they use non- } \\
\text { - oftandard strategies); } \\
\text { - consequently implements their plans by } \\
\text { creating situations facilitating it; } \\
\text { - tries predicting difficulties, which they consider } \\
\text { to be challenges and they try taking preventive } \\
\text { measures; } \\
\text { creative individualist, innovator of the role. }\end{array}$ & $\begin{array}{l}\text { - perceives difficult tasks as challenges that can } \\
\text { - engages in taking actions; } \\
\text { - sets ambitious objectives and aims for } \\
\text { implementation thereof; } \\
\text { - is characterised with high level of } \\
\text { determination in undertaken activities; } \\
\text { - their motivation to act is to a larger extent } \\
\text { conditioned by own beliefs than objective } \\
\text { situational conditions; } \\
\text { - the belief that they can achieve set objectives } \\
\text { motivates them to continue started ventures; } \\
\text { - discerns reasons for failures in their insufficient } \\
\text { efforts, possessed information or skills (factors } \\
\text { that are under their control); } \\
\text { - is convinced of their own ability to have control } \\
\text { in various situations, which reduces their stress } \\
\text { or lowers susceptibility to depression; } \\
\text { - has the skill to learn new things; } \\
\text { - - self-efficacy has a positive impact on their way } \\
\text { of thinking about themselves, self-assessment. }\end{array}$ \\
\hline
\end{tabular}

Source: own study on the basis of: Bateman, Crant (1993), Crant (1995), Fay, Frese (2001), Bańka (2016) (proactivity); Bandura (1998), Bańka (2016) (self-efficacy)

\section{Research exemplifications - proactivity in relation to self-efficacy}

Categories of a proactive personality, proactive behaviours, self-efficacy constitute variables broadly explored in the context of professional development. The 
research conducted in this area confirms their significant predictive value with regard to the individual's achievements in various spheres of functioning including experiencing successes in career. It turns out that the conviction of own predispositions to achieve set objectives improves professional functioning of teachers (Kowalczuk-Walędziak, 2012), the quality of teamwork (Łukasik, 2013), or educational achievements and professional adaptability of an individual (Larose et al., 2006; Klimkowska, 2013). Whereas, analyses devoted to pro-activity prove its close relations with information style of identity (Cybal-Michalska, 2013). This dependency confirms having certain personality features by proactive individuals, such as: openness to new experiences, willingness to learn about oneself and the surrounding world and auto-reflection. Peculiarity of their subjective initiative is demonstrated in the anticipation and active creation of the future, which, in the case of youth, is of crucial significance for shaping self.

Furthermore, the research related to the issue of professional career and referring to the construct of pro-activity, as well as beliefs in self-efficacy allow noticing many correlations between psycho-social variables. An example of which is given by own explorations conducted among the youth from complexes of vocational schools. ${ }^{1}$ The domain of general proactivity allowing recognition of proactive behaviours to the benefit of projecting professional development, as well as shaping the image of self as a person resilient to failures and flexible in activities, was recognised with the Scale of Career Proactivity by A. Bańka (2016). 10 statements referring to this construct were used in the questionnaire. Whereas, in order to assess the level of self-efficacy in action the Scale of Self-Efficacy by M. Urban (2008: 255) was used. This scale is made of 6 statements referring to five levels at which this efficacy can be represented. Whereas, in order to assess the level of self-efficacy in action the Scale of Self-Efficacy by M. Urban (2008: 255) was used. This scale is made of 6 statements referring to five levels at which this efficacy can be represented. The analysis of the empirical material indicated the directly proportional increase in the level of self-efficacy in action with regard to the increase in the level of respondents' general proactivity $(S ; \rho=0,267 ; p \leq 0.001){ }^{2}$

1 The studies were conducted in selected vocational and technical schools in the territory of the Greater Poland Voivodship and Kuyavian-Pomeranian Voivodship in 2015 with the diagnostic survey method. The study group consisted of 697 respondents. (See: Myszka-Strychalska, 2016).

2 The Spearman nonparametric rank correlation studying the dependence between variables (p-value indicates, whether this dependence is statistically significant) was used in calculation. $P \leq$ 0.05 value, which is commonly recognised in social sciences, was assumed as the limit level of statistical significance. The positive value of this coefficient shows that the tendency to act proactively increases along with the increase in the level of self-efficacy. 
Table 2. Correlation between the level of general proactivity and self-efficacy in action of the studied youth

\begin{tabular}{|l|c|}
\hline \multicolumn{1}{|c|}{ The level of self-efficacy in action } & ${\text { General } \text { proactivity }^{3}}^{\mathbf{3}}$ \\
\hline Very low & 31.6000 \\
\hline Low & 42.4348 \\
\hline Medium & 43.0659 \\
\hline High & 47.0892 \\
\hline Very high & 51.3152 \\
\hline
\end{tabular}

Source: results of own studies

Results of studies also allowed indicating a statistically significant correlation in the case of general proactivity $\left(\chi^{2}=157.102 ; d f=36 ; p \leq 0.001\right)^{4}$ and self-efficacy in action $\left(\chi^{2}=83.029 ; d f=24 ; p \leq 0.001\right)$ and the assessment of chances to succeed in career by the youth. It means that the higher the respondent's level of proactive behaviours in career, as well as belief in their own causal abilities in undertaken ventures, the higher he or she assesses own chances of professional success and vice versa; the lower the respondent's level of general proactivity and self-efficacy in action, the higher percentage of indicating the category "I have no chances" with regard to the perspectives of professional development.

Obtained results of studies correspond with other explorations conducted in the same area. The research conducted by R. Schwarzer, S. Taubert and E.R. Greenglass (1999) among Polish and Canadian respondents proves that proactive coping is positively correlated with self-assessment and self-efficacy, and negatively with professional burnout. Further studies conducted by E.R. Greenglass disclosed a highly significant relation of proactive coping and self-efficacy with the sense of just treatment at work (Greenglass, 2004: 147). Additional data on this topic is provided by explorations conducted by Manfred Diehl, Angellenia B. Semegon and Ralf Schwarzer indicating that both variables are also related to controlling attention in pursuing objectives, as well as resistance to distractors (Diehl et al., 2006). Whereas, explorations conducted among professionally active persons by Antje Schmitt and her co-workers indicated that persons declaring a higher level of efficacy on a given working day also demonstrated higher inclination to proactive activities (Schmitt et al., 2017). This data suggests that employers intending to increase professional effectiveness of their employees should undertake measures

\footnotetext{
${ }^{3}$ Values are given in the form of an arithmetic mean of results obtained by respondents showing a given level of self-efficacy.

${ }^{4}$ Chi-squared test was used to prove this dependency between variables.
} 
aimed at reinforcing belief in their own abilities. It is also important to promote behaviours of proactive employees, as it increases their engagement in the performed work and optimises their working environments (Dikkers et al., 2010). It is worth underlining that the level of noticeable efficacy in activity determines the quality of proactive and pro-developmental behaviours in career which are usually strengthened with reference to a specific professional field, in which the individual feels competent (Betz, 2004).

Den Hartog and Frank Belschak made some observations which are interesting in cognitive terms (2012). The research conducted by them among employees indicated a significant relation between self-efficacy and proactive behaviours, and the position held in the company. Persons holding managerial positions allowing autonomous actions were characterised with proactive behaviours and identified with a high level of trust in their ability to achieve set objectives. Whereas, employees holding positions characterised with low autonomy, did present proactive behaviours, however, it concerned only persons who disclosed low self-efficacy. Similar correlations were noticed in the case of self-assessment and employee assessments.

Explorations conducted by Majella J. Albion, Lorelle J. Burton, Karen M. Fernie (2005) among Australian unemployed persons allowed stating strong correlations between three variables: proactive coping, proactive attitude and general self-efficacy. They present cognitively interesting observations concerning the age of the respondents, which had a significant impact on answers given by the respondents. Persons with professional experience more often presented a proactive attitude and belief in self-efficacy than the youth starting their professional career. It means that adults notice potential in various changes and feel responsible for their professional development, which is manifested in their manner of thinking about their skills. Such manner of perception is less often shown by the youth. This observation has significant practical implications. It underlines the necessity of taking into consideration age differences and related needs while organising forms of support for the unemployed. For adults it is important to recognise and use their skills, which they obtained during their professional experience. Whereas, younger persons should be provided with trainings in the scope of specific strategies of coping in the labour market, which will probably produce desirable results.

However, it is worth mentioning that there are studies on the unemployed in the labour market indicating that a decidedly more important role in searching for a job is played by external factors such as the economic situation or existing social support than psychological factors, including self-efficacy (Kasprzak, 2000). A longer period of unemployment results in acquiring by a person a conviction 
that he or she has low abilities to find employment. What is more interesting, longitudinal studies conducted by M. Łaguna proved that persons participating in trainings aimed at reinforcing their belief in their own abilities did, in fact, show more faith in their potential, however, it did not result in getting a job (Łaguna, 2005).

\section{Summary and conclusions}

Proactivity and self-efficacy can be considered as components of attitudes, orientations, as well as personality features that direct the youth's behaviours at the achievement of specific aspirations and objectives in career. This observation gives grounds for the conclusion that individual motives resulting from own needs will constitute the basis of activity of the youth. Therefore, it means that the relation between the person's trust in their own effectiveness in achieving objectives and his or her behaviours, is not distant. Conducting explorations and analyses concerning self-efficacy and proactivity of the youth will allow predicting the course of their professional development in the future.

Observation of the proactivity construct in the context of constructing professional career enriches this area of analyses with the aspect of positive human efforts, emotions, aims, searching for benefits and sense in undertaken activities, as well as self-efficacy of actions. The individual's belief in successful completion of undertaken ventures motivates them to influence the surrounding environment and set new challenges, which, in consequence, reinforces their belief in possessed skills. Two factors play a significant role in the presented depiction: the development objective and time. Concentration on the achievement of set objectives allows undertaking measures preventing failures. Thus outlined perspective builds a bridge between theories of proactive coping and theories of actions and results in the inclusion of the theory of proactivity in the list of new theories of actions (Ratajczak, 2012). This observation entails a certain methodological hint that in all studies on categories of proactivity and self-efficacy a specific behavioural domain should be indicated, in the context of which such categories will be recognised (Betz, Hackett, 2006).

It is worth reinforcing self-efficacy and proactivity as soon as at the level of education. It requires creating situations allowing development of personal competences through interactions with the environment and other people, taking actions resulting from fulfilment of various roles and confrontation with potential threats (Bańka, 2015: 100). It is a difficult task which requires organisation of non-stand- 
ard trainings and situations. Shaping the youth's proactive attitudes and reinforcing their self-efficacy can produce desired results in the scope of the prevention of career indecisiveness, which is more and more often an individual's reaction to the unpredictability of contemporary times (Bańka, 2014).

Neglecting actions aimed at reinforcing the youth's belief in their own skills related to shaping the path of professional development can result in lowering their educational and professional aspirations, incomplete use of held resources, difficulties with making decisions or issues related with fulfilment of social roles (Krauze, 2012: 124). With regard to the procedures aimed at shaping the person's trust in their ability to control events, it is important to know psychological processes influencing the course thereof, such as: cognitive processes (the manner of perceiving events, developing scenarios of the course of action, selecting action strategies), motivational processes (formulating an objective that is important for the individual, expected result) affective processes (attitude to events, emotions as a source of information) and selection processes (estimation of own abilities with regard to the situation) (Bandura, 1993; Łukasik, 2013: 55-58). Therefore, it will be important to develop the youth's competences of analytical thinking, obtaining information on the environment and self, long-term planning, recognising and naming own feelings and realistic assessment of own predispositions to take various actions.

Proactivity and self-efficacy of the youth reinforce their responsible engagement in the process of constructing a career. They constitute factors significantly related to motivation to act, which, by stimulating their causative potential, influences effectiveness of performed tasks, coping with them or creating ambitious plans of professional development. Thus, shaping them at the youth constitutes one of the basic educational tasks.

\section{Bibliography}

Albion M.J., Fernie K.M., Burton L.J. (2005), Individual differences in age and self-efficacy in the unemployed, Australian Journal of Psychology, 57(1), pp. 11-19.

Bandura A. (1993), Perceived self-efficacy in cognitive development and functioning, Educational Psychologist, 28(2), pp. 117-148.

Bandura A. (1994), Self-efficacy, [in:] V.S. Ramachaudran (ed.), Encyclopedia of Human Behavior vol. 4, pp. 71-81, New York.

Bandura A. (2015), Teoria społecznego uczenia się, Warszawa.

Bańka A. (2006), Poradnictwo transnacjonalne. Cele i metody międzykulturowego doradztwa karier, Warszawa.

Bańka A. (2007), Psychologiczne doradztwo karier, Poznań. 
Bańka A. (2009), Proaktywność - inencjonalne konstruowanie przyszłości i uprzedzające osiąganie celów personalnych poprzez doświadczanie codzienności, [in:] H. Wrona-Polańska, W. Czerniawska, L. Wrona (eds.), Szkice o ludzkim poznawaniu i odczuwaniu, Kraków.

Bańka A. (2013), Zaufanie do siebie w procesie konsolidacji statusu dorosłości: Konstrukcja i charakterystyka psychometryczna Skali Samoskuteczności w Karierze, Czasopismo Psychologiczne, 19, 2, pp. 281-301.

Bańka A. (2014), Bezdecyzyjność jako psychospołeczny wzór tranzycji do dorosłości: Konstrukcja Skali Decyzyjności Kariery, Czasopismo Psychologiczne, 20, 2, pp. 237-246. DOI: 10.14691/ CPPJ.20.2.305.

Bańka A. (2015), Intencjonalne konstruowanie przyszłości i wyprzedzające realizowanie celów: walidacja Skali Proaktywności Ogólnej, Czasopismo Psychologiczne, 21, 1, pp. 97-115.

Bańka A. (2016a), Poczucie samoskuteczności. Konstrukcja i struktura czynnikowa Skali Poczucia Samoskuteczności w Karierze Międzynarodowej, Poznań-Warszawa.

Bańka A. (2016b), Proaktywność a tryby samoregulacji. Podstawy teoretyczne, konstrukcja i analiza czynnikowa Skali Zachowań Proaktywnych w Karierze, Poznań-Warszawa.

Bateman T.S., Crant J.M. (1993), The proactive component of organizational behavior, Journal of Occupational Behavior, 14, pp. 103-118.

Betz N.E. (1992), Counseling uses of career self-efficacy theory, Career Development Quarterly, vol. 41 , is. 1 , pp. $22-26$.

Betz N.E. (2004), Contributions of self-efficacy theory to career counseling: a personal perspective, Career Development Quarterly, vol. 52, is. 4, pp.. 340-353.

Betz N.E., Hackett G. (2006), Career self-efficacy theory: back to the future, Journal of Career Assessment, 14(1), pp. 3-11.

Cervone D. (1997), Social-cognitive mechanisms and personality coherence: self-knowledge, situational beliefs, and cross-situational coherence in perceived self-efficacy, Psychological Science, vol. 8, pp. 43-50.

Crant J.M. (1995). The proactive personality scale and objective job performance among real estate agents, Journal of Applied Psychology, 80, pp. 532-537.

Crant J.M. (2000), Proactive behavior in organizations, Journal of Management, 26, 3, pp. 435-462.

Diehl M., Semegon A.B., Schwarzer R. (2010), Assessing attention control in goal pursuit: A component of dispositional self-regulation, Journal of Personality Assessment, vol. 86, is. 3, pp. 306-317.

Dikkers J.S.E., Jansen P. G.W., de Lange A.H., Vinkenburg C.J., Kooij D. (2010), Proactivity, job characteristics, and engagement: a longitudinal study, Career Development International, vol. 15, no. 1, pp. 59-77.

Drwal R.L. (1995), Poczucie kontroli jako wymiar osobowości - podstawy teoretyczne, techniki badawcze i wyniki badań, [in:] R.L. Drwal (ed.), Adaptacja kwestionariuszy osobowości. Wybrane zagadnienia i techniki, Warszawa, pp. 199-227.

Fay D., Frese M. (2001). The concept of personal initiative: An overview of validity studies, Human Performance, 14(1), pp. 97-124.

Frese M., Fay D., Hillburger T., Leng K., Tag A. (1997), The concept of personal initiative: Operationalization, reliability and validity in two German samples, Journal of Occupational and Organizational Psychology, 70, pp. 139-161.

Frese M., Kring W., Soose A., Zempel J. (1996), Personal initiative at work: Differences between East and West Germany, Academy of Management Journal, 39, pp. 37-63. 
Grant A.M., Ashford S.J. (2008), The dynamics of proactivity at work, Research in Organizational Behavior, 28, pp. 3-34.

Greenglass E.R. (2004), Różnice wynikające z ról płciowych, wsparcie społeczne i radzenie sobie ze stresem, [in:] H. Sęk, R. Cieślak (eds.), Wsparcie społeczne, stres i zdrowie, Warszawa.

Greenglass E.R., Schwarzer R., Taubert S. (1999), The Proactive Coping Inventory (PCI): A multidimensional research instrument, http://www.psych.yorku.ca/greenglass/.

Griffin M.A., Neal A., Parker S.K. (2007), A new model of work role performance: Positive behavior in uncertain and interdependent contexts, Academy of Management Journal, 50(2), pp. 327-347.

Hartog D.N., Belschak F.D. (2012), When does transformational leadership enhance employee proactive behavior? The role of autonomy and role breadth self-efficacy, Journal of Applied Psychology, 97(1), pp. 194-202.

Hobfoll E. (2006), Stres, kultura i społeczność, Gdańsk.

Kasprzak E. (2000), Osobowość młodych bezrobotnych a sukces i porażka na rynku pracy, Czasopismo Psychologiczne, 6, 1-2, pp. 55-61.

Klassen R., Chiu M.M. (2010), Effects on teachers' self-efficacy and job satisfaction: Teacher gender, years of experience, and job stress, Journal of Educational Psychology, vol. 102(3), pp. 741-756.

Klimkowska K. (2013), Orientacja na sukces zawodowy studentów kończacych studia translatorskie, Lublin.

Kowalczuk-Walędziak M. (2012), Poczucie sprawstwa społecznego pedagogów. Studium teoretyczno-empiryczne, Kraków.

Krauze E. (2012), Poczucie samoskuteczności studentów w karierze (komunikat z badań), Problemy Profesjologii, no. 1, pp. 121-134.

Larose S., Ratelle C.F., Guay F., Senécal C., Harvey M. (2006), Trajectories of science self-efficacy beliefs during the college transition and academic and vocational adjustment in science and technology programs, Educational Research and Evaluation, vol. 12, is. 4, pp. 373-393.

Lent R.W., Hackett G. (1987), Career self-efficacy: Empirical status and future directions, Journal of Vocational Behavior, vol. 30, is. 3, pp. 347-382.

Łaguna M. (2005), Spostrzeganie własnej skuteczności i koncepcja Ja u osób bezrobotnych. Możliwości modyfikacji poprzez działania edukacyjne, Psychologia Rozwojowa, 10/1, pp. 69-78.

Łukasik I.M. (2013), Poczucie własnej skuteczności we współpracy z grupą. Eksperyment pedagogiczny $w$ przestrzeni akademickiej, Lublin.

Maddux J.E., Lewis J. (1995), Self-efficacy and adjustment. Basic principles and issues, [in:] J.E. Maddux (ed.), Self-efficacy, Adaptation and Adjustment: theory, research and application, New York, pp. 37-68.

Morrison E.W., Phelps C.C. (1999), Taking charge at work: Extra role efforts to initiate workplace change, Academy of Management Journal, 42, pp. 403-419.

Myszka-Strychalska L. (2016), Orientacje zawodowe młodzieży z zespołów szkół zawodowych, Poznań.

Parker S.K., Williams H.M., Turner N. (2006), Modeling the antecedents of proactive behavior at work, Journal of Applied Psychology, 91(3), pp. 636-652.

Ratajczak Z. (2012), Przedsiębiorczość w kontekście ogólnej teorii działania, [in:]: Z. Ratajczak. Przedsiębiorczość. Źródła i uwarunkowania psychologiczne, Warszawa, pp. 13-26.

Schein E. (1971), The individual, the organization, and the career: a conceptual scheme, The Journal of Applied Behavioral Science, vol. 7, is. 4, pp. 401-426.

Schmitt A., Belschak F.D., Den H., Deanne N. (2017), Feeling vital after a good night's sleep: The interplay of energetic resources and self-efficacy for daily proactivity, Journal of Occupational Health Psychology, vol. 22(4), pp. 443-454. 
Schwarzer R., Taubert S. (1999), Radzenie sobie ze stresem: wymiary i procesy, Promocja Zdrowia, Nauki Społeczne i Medycyna, 17, pp. 72-92.

Schwarzer R., Taubert S. (2002), Tenacious goal pursuits and striving toward personal growth: Proactive coping, [in:] E. Frydenberg (ed.), Beyond Coping: Meeting Goals, Visions and Challenges, London, pp. 19-35.

Seibert S.E., Crant J.M., Kraimer M.L. (1999), Proactive personality and career success, Journal of Applied Psychology, 84(3), pp. 416-427.

Slebarska K. (2017), Droga do pracy. Proaktywne radzenie sobie a poszukiwanie zatrudnienia i adaptacja do nowego miejsca pracy, Katowice.

Turska E. (2014), Kapitał kariery ludzi młodych. Uwarunkowania i konsekwencje, Katowice.

Urban M. (2008), Indywidualizm i kolektywizm w świadomości młodzieży. Studium psychologiczno-polityczne, Warszawa. 